\section{Frederik IIs og Christian IVs Foliobibler}

\author{
Aftypograf og bibelsamler Hans Beckhang, \\ Hvaler, Norge, med forord affhv. skoleleder \\ Peter Raes
}

\section{Forord}

Thristian IVs foliobibel fra 1632-33

(begge årstal findes i bogen på

titelbladene og i kolofonen, da trykkearbejdet stod på i godt et år) var efter kongens ønske en kopi af hans faders bibel fra 1588-89, den såkaldte Frederik IIs bibel. Den skulle trykkes med de samme skrifttyper og de samme billeder i træsnit, således at blad svarede til blad og linie til linie. Disse retningslinier blev for det meste nøje fulgt, dog med de små ændringer og tilføjelser, især kongeportrættet og versinddeling, ${ }^{1)}$ som er beskrevet i detailler af Ingrid Ilsøe i hendes artikel "De tre danske foliobiblers historie, træsnit og stik". ${ }^{2)}$

Papiret til denne nye, fornemme kirkebibel var bestilt hos Pieter Hach i Amsterdam, "1700 ris stort fint hollandsk papir" og "Smukt medianpapir", noget af betydeligt bedre kvalitet end i Frederik IIs bibel. Leveringen blev i øvrigt forsinket en del, til ret store omkostninger for universitets- trykkerne, Salomon Sartor og Melchior Martzan, som måtte betale deres 6 trykkersvende ventepenge.

Skrifttyperne til denne udgave skulle, som sagt, være de samme som i Frederik IIs bibel, men med den slitage på dem, som den foregående trykning af ca. 2.500 bibeleksemplarer samt følgende bøger fra 15891632 ville have voldt, er det klart, at nye typer skulle støbes, en ganske almindelig fornyelsesproces i bogproduktion. Vi ved for eksempel, at Sartor havde fàet Mads Vingaards træskårne illustrationer til den tidligere bibel ${ }^{3)}$. Men hvor nøjagtig er gengivelsen af den ene bibels skrift blevet gennemført i den anden, rent teknisk? Dette emne er blevet behandlet generelt for alle tre foliobiblers (Chr. III, Fred. II og Chr. IV) vedkommende af nordmanden Jakob Rask Arnesen ${ }^{4}{ }^{4}$ men mig bekendt er det ikke før blevet gennemgået i detailler af en typograf udelukkende for disse to sidste biblers vedkommende.

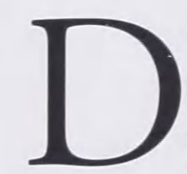
e mange forskelle, når det gælder skriftsnit (skrifttyper), mangel på konsekvens, håndskrevet manus, tydelige spor af at mange sættere deltog i arbejdet og måske også forskellige korrekturlæsere, har den norske typograf Hans Beckhaug nu påpeget i sin artikel. Han har også givet os mange henvisninger til eksempler på, hvad han taler om, som den ivrige læser let kan finde ud af ved selv at se efter.

Peter Raes 


\section{Kirkebiblenes typografiske mangfold}

\author{
En sammenligning mellom \\ Frederik II's og Christian IV's bibel
}

Med ordforklaringer

Av Hans Beckhaug, Hvaler, Norge

$\mathrm{F}$

rederik II's bibel var den første bibel trykt av en dansk boktrykker, Mads ble trykt i samarbeid mellom Melchior Martzan og Salomon Sartor. Begge disse folianter var reviderte utgaver av Christian III's bibel av 1550, og alle tre var svært kostbare og kom ut i folioformat. ${ }^{5)}$ Teksten er trykt i to spalter og satt med fraktur, og schwabacher er brukt i register og marginaltekster. ${ }^{6}$ Til skriftgruppen fraktur hører gotisk, schwabacher og kanselli. Den rene fraktur ble brukt fra ca. 1520 og har vært dominerende i Tyskland helt inn i 20 . århundre. I en tysk håndbok fra 1926 f.eks. omtales ikke mindre enn 375 forskjellige fraktursnitt.

Historien forteller at trykkerne av Chr. IV's bibel fikk 400 daler i forskudd til innkjøp av nye skrifter. Bibelen skulle settes med samme brødskrift, illustrasjoner og typografisk oppsett som i Fred. II's bibel. Vi vet at illustrasjonene og store initialer som er skåret i tre ${ }^{7)}$ er de samme brukt i begge bibler. Det er tydeligt at forberedelsene var bedre ved utgivelsen av Chr. IV’s bibel. Skrift støpt i samme snitt ble kjøpt inn i mengder, slik at setterne har hatt nok å ta av under arbeidet.

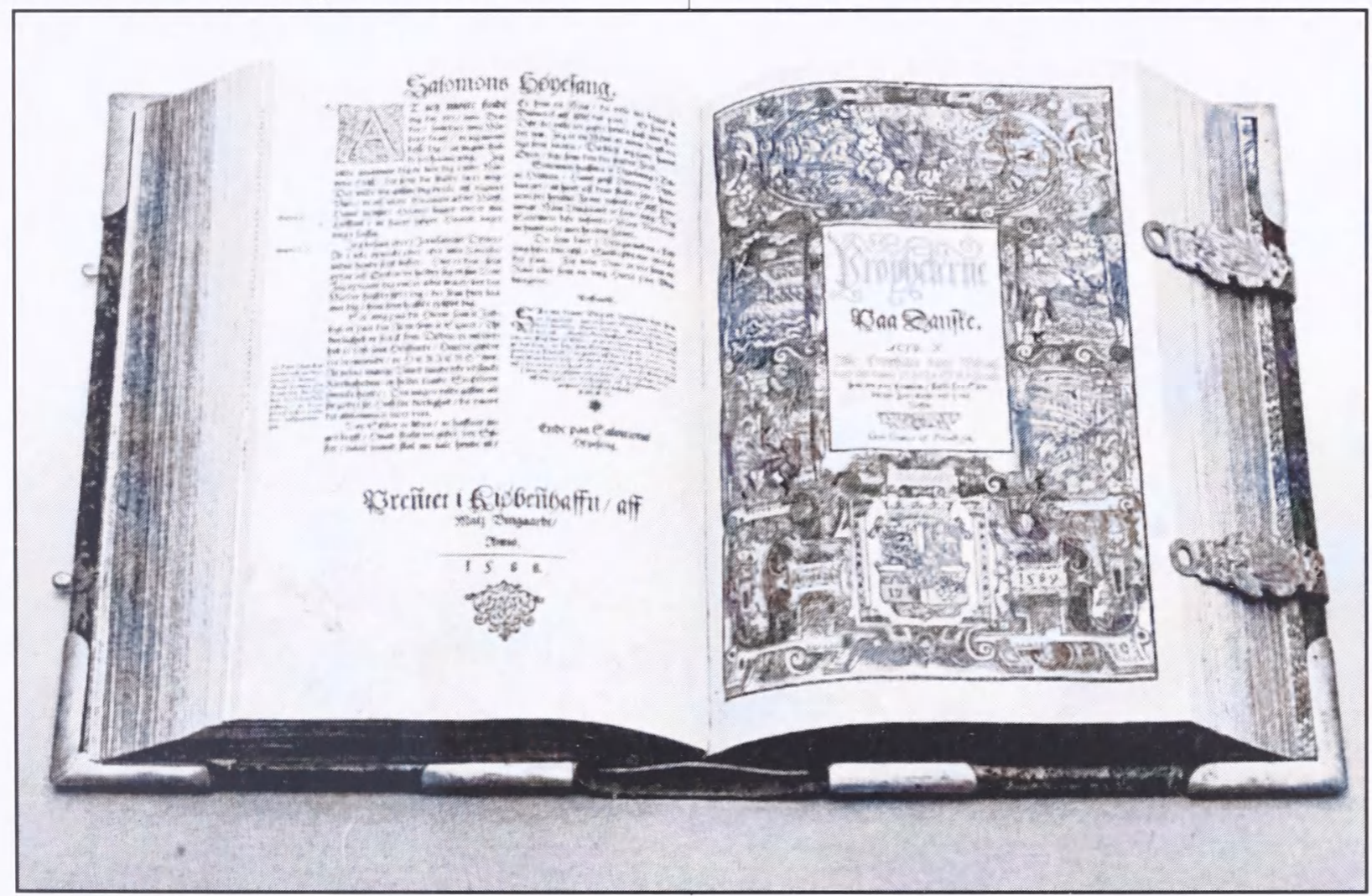

5. Frederik II's foliobibel. Disse bibler var veldig store og tunge, ofte med beslag og spenner i messing som her. (Foto: Det Kongelige Bibliotek) 


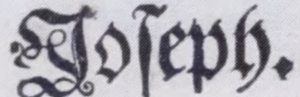

Tofeph or Saano/oc flaxodefantmen i buit Eildfe

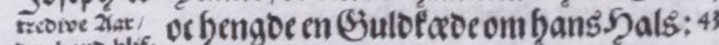
oex hant blif, De loobannem agepaa fin antern 2 ogn sørite/tis aar oc loo uoraabe for baimem/ b Sano er elenbighes oc Zanofens faber / of fixtte banmen ofuer sangiel. Ifos gantfle Egnpti \&ano. 44 Dr Dharav fags 2ar for eno Detil jo/eph/ieg er Pbarao: 2 ben oin bi: an sorfte. lieftal ingen róre in Saano eller in foo

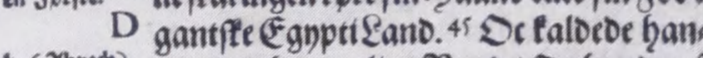
b (2tbrech) nem Det bemmelige Raao/De bano gaf beser/laoe vi bannem \&inath til Şufru/fom vaar Po: ocm fom Fifue tiphere Dreftis Daatter iDn: Saafoer

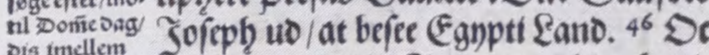
vis imellem foritar bano vaar treoive War gammel/oer bano

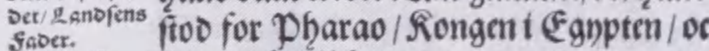
Qinath foer uo fra Dharao / oc rengoc igenmen jofephs gantifte Egyptizano. 47 Dr Eander bar of ucrflodig fructioe fiurige aar. ${ }^{48} \mathrm{O}$ (b̧and faunledeidefiu 2lar alloen Epifning/form baar $i$ Egnpti Eano/ oc lagoe Den ino $i$ Etcxorne: Suadoer vortepaas?arcfe ne omfring buer Etab til Eptining/Det lagoedebenino. 49 Saafamieoe jofeph Rorn tillęobe / ofuermaade meget / fom Sandenved Şafuet / faa / at f̧and loo af at talle oet/ Fhtmano funbe oet iffe talle.

Jofephs so J Soreph afledeto Eonner for eno

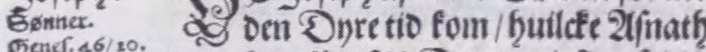
Oe 48/10. Potiphere Preftis Daatter $t$ On fodoc (Danaffe) hannem. II Orfaloede ben forfie SYanaf

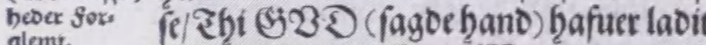
glemt. mig forglemme all min \$2700gang/oc aft min faders Sus. ${ }^{2}$. Den anden faldede (Epfraim) band Ephraim/ Thi Siud ( Fagoc band) Ealors epp bafuer laoitmig voxei oette \&ano/fomjeg voren. baar Elenoiguot.

13@ Er be fiu fructionme 2lar baare nt pralm. 105/16. Osfremgangnei Egupti\&ano: 44 Da Dne tio begnnte oe fiu onre 2lar at fomme/builcfe fiu zart Ja Jofephbafoe talit om. Or Der blefen Onr tio t alle Eano: SZen oer vaar Brob gantife (Egupti Eano. " Der nu Det gant: fee Eanpti Eano oc leeo 5unger/raabte Foldet til Pharao om 3 roo: $\$ 2 Z e n$ Pha rao fagde tilalle Egnpterne/Sjaar ben til Jofeph / oc b̧uad b̨ano figer eoer / giorer oet. 56 Der nut i oet gantfte Eano vaar Dnetio/Daoploo Sofeph alle ftede Rorn Gus/oc foloe Egnpterne/ thit oen Onre tio blefio langer io fitarrei iandet. 57 De alle Eano fomme ino i Egnpten/at fobc af Yos ieph/thidoen Dnretio vaar fiorialle Eano.

\section{2.}

\section{$\mathrm{X}$ LII.}

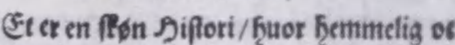

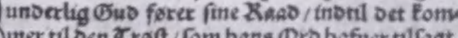

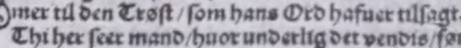
eno den orerm fulotemmis / fom Zofeph bafoe fagt fine

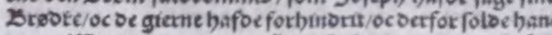

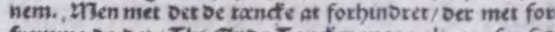
fremmec oe Det / Ebt Guos Eand'a maace alt gan for fig

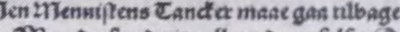

Men be fagoe imellem bem felf / Dette fiafue vi forfenldit paa vor Broder/ett. Det ex et finuct if empel on Jofephs brebre/ huorlests deris Gantivitrig

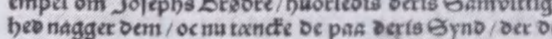
morte lange fioen befue glemt. idéf forglemme hun vil greve bienter wroligt huso bellex Det feer feent eller frart. Detr or Rat mano rage fig vare

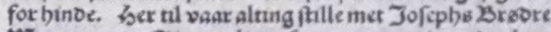
$215 e n$ nu motte Bimeon liggefangen / oc mer be anbre bas:

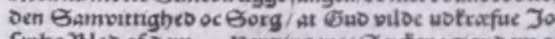

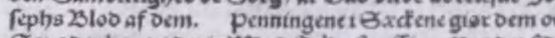

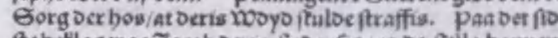

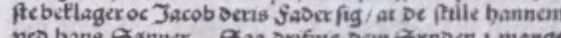
ver bans Brinter. Gaa Drifurs ban Bynden 1 mange

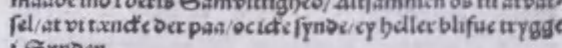

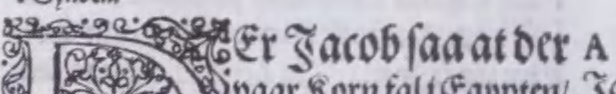

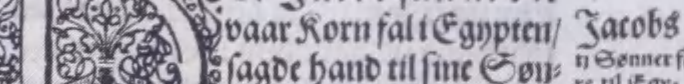

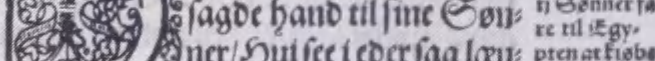
acjor. at oer fellis Rorni 1 ( $g y)$ pten: farer benned/oc fiober os Rorn/at bi fumoe lefuc/ oc ide Do. ${ }^{3}$ Eaa fore jos fepbs ti Breore ben ned / at flabe fiorn i

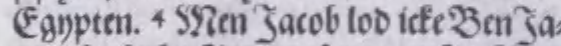
min sofeph 3 Broder fare met fine 3 ros ore: Ehthano fagoe/5̧amem motteno: gen 23 indtevederfaris.

s Eaa fomme sfraels $\mathfrak{r}$ orn at liobe Rorn/met anore fom fore met oem: ?bit Det vaar oc onrt i oet Eano Sanaan. (S Jofeph vaar Regenteri Eandet/oc as bano foloc alt foldet izanoet fiorn: Derhans Brobre fommenutil b̨annem!/ fuldedened til jorbenforbannempaade

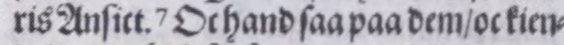
Dedem/ocholt/igfremmeomod oem/octa led frart met Dem/oc fagoe til Dem/Şux. Denfommei: Defagoc/af det \&anosana an/at fiabe Epife.85yen alligevelat ţand fiende Dem/ faafiende be f hannem oogicfe.

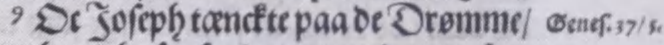
fombano hafoefor oremt om dem/ocfag. Detildem/sere Epenerc/ oc ere forne at bejee/buor \&andet er obet. ${ }^{10}$ De fuarede bannem/2Ren/min Serre : Dine vienere erefomne at fidbe Epife. II 21 ere alle en S2anos Eonner: 31 ere arlige/oc oine 
Salomon Sartor har trykt 452 sider og

Melchior Martzan 1024 sider.

Men det er mange forskjeller å oppdage ved å sammenligne Fred. II's bibel med Chr. IV's bibel. Spaltebredden i Fred. II's bibel er på $80 \mathrm{~mm}$, mens Chr. IV's bibel er på $78 \mathrm{~mm}$. Sistnevnte har også fătt nummerert versinndeling i teksten. Likevel vet vi at setterne av Chr. IV's bibel har brukt Fred. II's bibel som forbilde, da teksten stort sett følger side for side. De mange pagineringsfeil i kirkebiblene omtales i boken "På Sporet af gamle Bibler - en nordisk Antologi",
København 1995.

Innledende avsnitt med initialer og større typer har et helt nytt snitt i Chr. IV's bibel. I denne er f.eks. initialen E mer høyreist i "kroppen" og enklere i buene. Seriffene i overkant er større. Ved nærmere studie har samme initial store variasjoner og mye kan tyde på at disse er skåret i tre. Dette kan vi bl.a. se i NT på side 70 og 122 b stor D, og stor $S$ på side 124, $124 \mathrm{~b}$ og 175.

Kapitlenes nummerering med romertall har samme skriftgrad i begge bibler, men snittet er forskjellig og bokstavene er bredere i Fred.

\section{\&ostat.

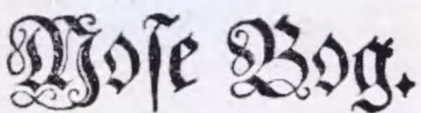

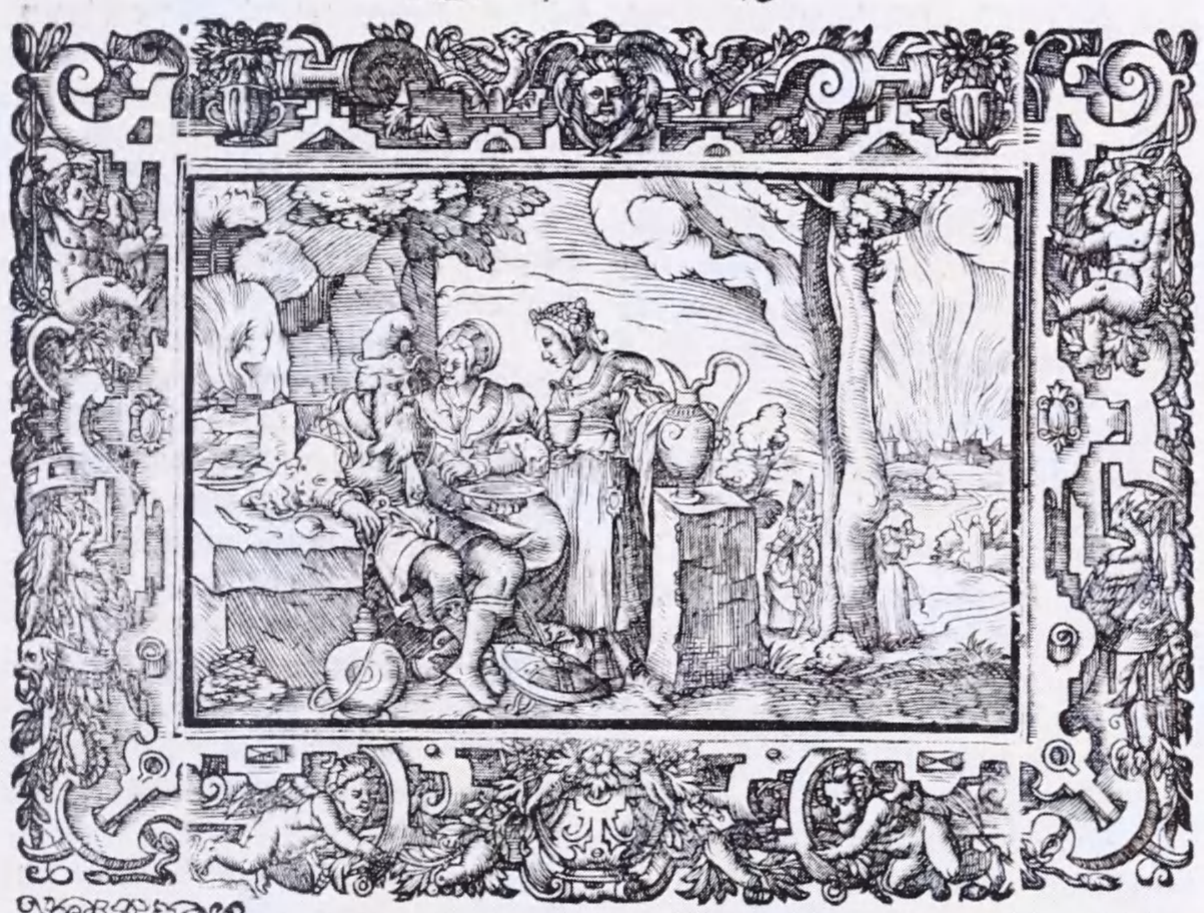

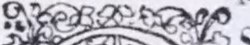

A

aste. $13 / 2$.

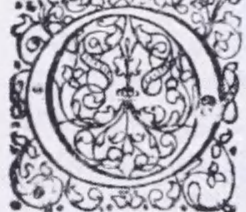

- $3 \mathrm{~g} 3 \mathrm{e}, \mathrm{C}$ bañ til jortu. ${ }^{2}$ Or fagoc/Ere/HCEXXEl founmer oog ino met migi coers Eicneris for ere oe inogangne at ftiule ocm unoer mit ₹ag. 9 Defagoc/Dafom ou bio/De Defagoc noermere/ Omme enife fremmes ocftuloe bano fomme oc Demme? $3 \mathrm{el}$ oi villeplage otgmeremo oem: Eaatrang B oc oebart ino paa oen \$sano gotb/oc lo: betil/at brinoe Dorren op. 10 Saracte slanoene uo/or toge goth ino in ufet til

7. Tresnittsillustrasjonene i Christian IV's bibel var overtatt av trykkeren fra hans forgjenger Mads Vingaard, trykker av Frederik IIs bibel. (Foto: Det Kongelige Bibliotek). 
II's bibel. Stor I er tykkere i kroppen i Chr. IV's bibel. (Se f.eks. side 140 i GT). Det virker som om disse er skåret i tre i Fred. II's bibel. Tilsvarende bokstaver i Chr. IV's bibel er like og tyder på støpte typer. Se f.eks. romertall I, II, og III i kapitlenes nummerering.

I Frederik II's bibel er der i romertall fire, fjorten, tjuefire, trettifire osv. konsekvent brukt IIII, mens i Christian IV's bibel er romertall fire skrevet forskjellig, noe som alle lett kan se. Det ser ut som setteren skulle rette til det korrekte IV, men IIII er brukt mange steder. I begge bibler forekommer kapitteltall som avslutning på en spalte, altså starten på neste kapittel. Dette blir på fagspråk kalt "fransk horunge" og burde vært unngått. En ekte horunge er når en avsluttende linje i en paragraf (kanskje bare to-tre ord) står øverst på en venstreside i et oppslag.

Majuskler i brødteksten, f.eks. ordene HERREN - HERRENS, har en annen gravyr enn den øvrige tekst. Sammenligner du stor $\mathrm{S}$ legger du merke til markante forskjeller i snittet. Dette gjelder i begge bibler og kan tyde på at skrift fra forskjellige støperier eller gravyr er blandet. Disse versalene er mindre enn brødskriftens, men kan kalles kapitéler, selv om de ikke holder skriftens x-høyde. Det eneste stedet i Chr. IV's bibel jeg har funnet riktige kapitéler er på side 155 i GT i første spalte, uten at jeg har foretatt en grundig gjennomgang av hele Bibelen. I profeten Jeremias kap. III (side 35) i Chr. IV's bibel er "kapitéler" brukt i ordet HERREN på den ene spalten, mens versaler av skriften er brukt i spalte to med ett unntak. Dette er noe vi ser mange steder i teksten.
Bibelens kolumnetittel ser ut til å være skåret i tre i begge disse kirke-bibler. Bokstavene varierer i snitt og høyde. Det er også skåret spesielle avslutninger på enkelte bokstaver. I flere tilfeller er punktum skåret inn i bokstaven, noe som ikke ville forekomme hvis de var satt med løse typer. Punktum etter kolumnetittel varierer også fra stjerne, korslignende og rundt. I Jobs bok i Chr. IV's bibel kommer disse forskjeller klart fram. I Esras bok i GT side 254b og utover ser vi kolumnetittelen, bokens navn, skrevet på forskjellige måter - Esdræ Bog og Esdre Bog. Vi kan også se forskjellige punktum hele veien. Likevel er det slik at bokstavenes høyde varierte en god del, og det var først i 1905 at skriftstøperiene i Tyskland gikk sammen om "normal-skriftlinje".

I Fred II's bibel kan vi se skrift med forskjellige skriftsnitt på hver enkelt side. Hvor stor initial D forekommer mange ganger, kan vi se hele fire forskjellige snitt i ett oppslag. For studium kan vi se i Chr. IV's bibel på versal S på sidene $34 \mathrm{~b}$ og $35 \mathrm{i}$ NT, hvor de forekommer i mengder. 120 stk. i skriftens versaler og 43 stk. i mindre grad som har et helt annet snitt. Den mindre grad er brukt på side 34b i mangel på versal S av skriften, mens på side 35 ser vi versaler av skriften brukt. Dette tyder på flere forskjellige støpninger eller ulik gravyr og kanskje de er støpt ved forskjellige skriftstøperier.

Sammenstøpte bokstaver (ligaturer) har flittigt vært brukt i begge bibelutgivelser. I tillegg til de for oss mest vanlige ser vi også $\mathrm{ch}, \mathrm{ft}, \mathrm{sc}, \mathrm{sk}, \mathrm{sr}$ og st brukt. I marginalene har bokstaver som A, B og C helt forskjellig skrift i Fred. II's bibel og Chr. IV's bibel. Orddelingen i margen er forbedret og mer konsekvent i Chr. IV's bibel, noe vi kan se i 
GT på side 123, Gibeo-, Gibeoni-. Kustoder er brukt i begge bibler. Ordene GUD eller GUDS er i Chr. IV's bibel satt med versaler av brødteksten. Det samme er ordene HERREN - HERRENS hvor teksten starter med en initial. Dette er forandring fra Fred. II's bibel som lett kan ses i f.eks. Salmenes bok, side 293.

I Fred. II's bibel skjemmer de mange trykkfeil (skrivefeil) og vi må vel si at korrekturen har vært for dårlig. Ved å lese igjennom en side og bare se på ordene HERREN, HERRENS framhevet i versaler, vil vi stadig finne skrivefeil og mangel på konsekvens. Eksemplene som jeg gjengir her er hentet fra GT sidene 69, 136 og 140: HEREEN, HEREN, HERren, HERRens, HErrens. Disse feilene kan vi se flere ganger på enkelte av sidene. På en spalte på side 69 ses disse feil hele 4 ganger.

I Chr. IV's bibel er mange av disse typografiske "skjønnhetspletter" rettet, selv om noen av de gamle forekommer ennå, og noen nye er kommet til. Vi kan se på side 312b i GT ordfeil som HERRNES. På side 221 b siste linje ser vi ordet HERREN skrevet HENNEN i skriftens versaler. En blanding av versaler og minuskler i ordet HERREN kan vi bl.a. se på sidene 53b, 120, 213b, 217, 219 og 228b i GT og side 32b i NT. I GT på side 232 f.eks. er skriftens versaler brukt 3 ganger i ordene HERREN HERRENS, mens HERrens, HERRens forekommer 9 ganger. I Fred. II's bibel er det ingen av disse feil på denne side men derimot HErren 2 ganger i de siste 10 linjer.

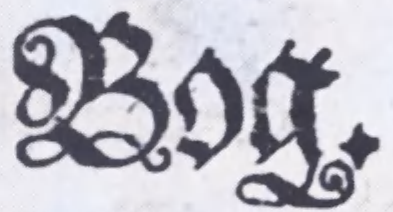

\section{ISS.}

offuer off? Saver bem formme fio / at soi fla bem ibiel. Eaulfagoe/ Derfeal in" gen op paa denue dag Thi S E $x x$ E boffiter i ong giffuit Ealigheo i J frael.

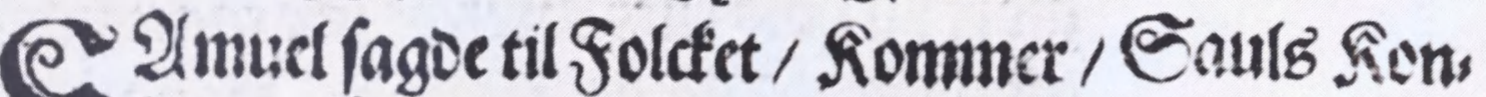
D) laver ofl gaa til Sillgal/oc Der foran gerigis forneclio.

Sionge'Siget. Da gict alt foldet til Gilgal / or giorie Eaul til Siongefaar

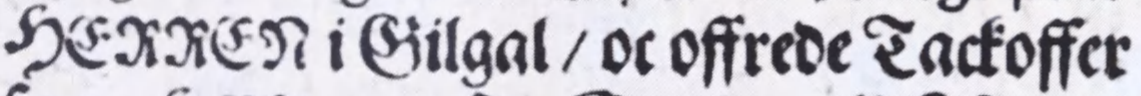
faar Syexiren: Sc Eaul oc alle Jiraelb Sy ento gíado orm oer gantffe megit.

8. Det spesielle 5-tall i pagineringen, Frederik II's bibel. (Foto: Det Kongelige Bibliotek). 


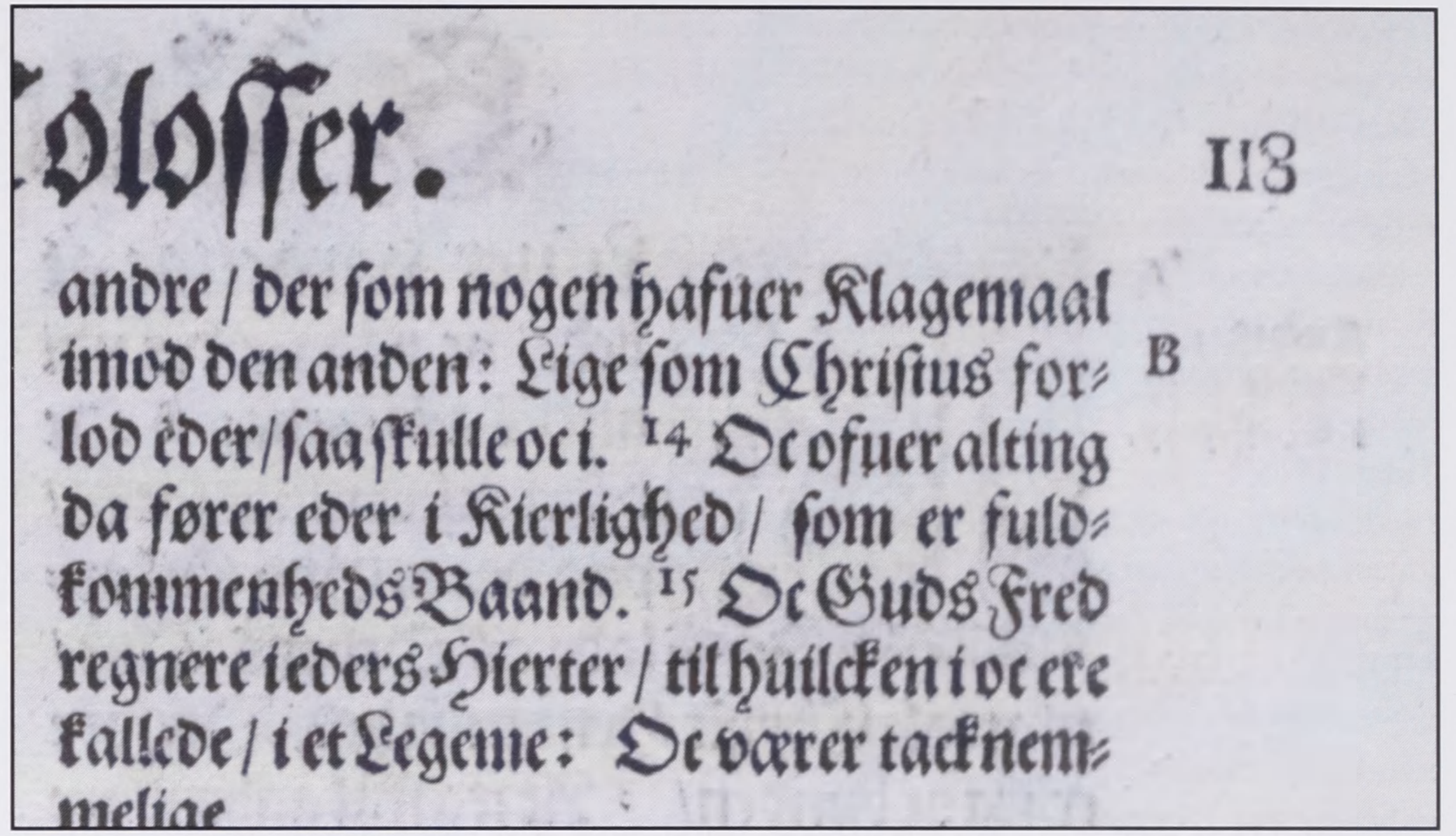

9. Christian IV's NT, folio 113. Folio 110-119 viser tydelig i pagineringstallene forskjellige tykkelser på bokstavens kropp. (Foto: Det Kongelige Bibliotek).

Igjen på side 295 i Salmenes bok kap. 28, 29 og 30 ser vi skriftens versaler brukt 11 ganger og kapitéler 19 ganger, altså en stor blanding av skriftgrad.

Også i Fred. II's bibel er romertall (I) brukt konsekvent gjennom hele Bibelen, men enkelte skiller seg ut ved slankere snitt i bokstavens kropp. Dette ser vi lett f.eks. på side 111,112 og 121 i NT. 5 -tallet ${ }^{8}$ i pagina gjennom hele Bibelen har et snitt jeg har vanskelig for å bli fortrolig med.

Bøkenes paginering (sidetall) er forskjellig. Det er brukt skriftens tall og romertall (I) om hverandre. Punktum etter pagina er sløyfet i Chr. IV's bibel. Vi kan også se romertall (I) brukt i versinndelingen, selv om første vers alltid mangler tall. Ved bruk av pagina i romertall er det blitt brukt forskjellige støpninger. Se side 110-119 i NT hvor forskjellige tykkelser på bokstavens kropp klart kan ses. ${ }^{9)}$ Ved bruk av flere romertall (stor I) er det tykkeste alltid satt først. Denne variasjon i sidetallenes skrift kan lett ses og viser selvfølgelig mangel på konsekvens. På side 228 i GT i alle eksemplarer av Chr. IV's bibel står pagina 328. Vi legger også merke til at 2-tallet er en grad mindre enn de øvrige tall - altså to feil i dette ene sidetallet. I marginalen nederst på siden ser vi også en "fisk" i ordet GUDS, hvor versal S er en grad mindre. En riktig "brøler" finnes i GT side 222, hvor Den Første Krønicke Bog kalles Den Første Kongernes Bog.

Selv med variasjon i mengden av trykksverte og trykkpreg av sidene, ses lett variasjon i typesnitt. Flere settere var delaktig i dette store arbeid og de tall man hadde for hånden ble brukt. Når man likevel ser at enkelte sider innimellom en serie har andre tall, kan man fristes til å tro at læregutter har satt enkelte sider som øvelse - derav resultatet. 
Ved gjennomgåelse av ett-tallene i pagineringen av Chr. IV's bibel får vi disse variasjoner:

Det gamle Testamentet:

Skriftens tall side 1-81, 115-210 og side 261.

Romertall side 91-114, 211-251 og side 271-351.

Profetene:

Skriftens tall side 71, 105, 106, 110, 113, 115-221, derav side 187 to ganger.

Romertall side 10-61, 81-104, 107-109, 111,112 og side 114 .
Det nye Testamentet:

Skriftens tall side 21, 51, 61, 131 og side 145-157.

Romertall side 10-19, 31, 41, 71-130, 132144 og side 158 .

I enkelte tall i pagineringen i Chr. IV's bibel er det brukt stor bokstav (versal) istedenfor tall. Se f.eks. stor bokstav O i GT pagina $100^{10)}$ som er en blanding og virker fremmed.

Store initialer skåret i tre $(45$ x $45 \mathrm{~mm}$ brukt som start av nye bøker og 32 x $32 \mathrm{~mm}$ som initial for begynnelse på nytt kapittel) er skåret av samme kunstner, og likheten i
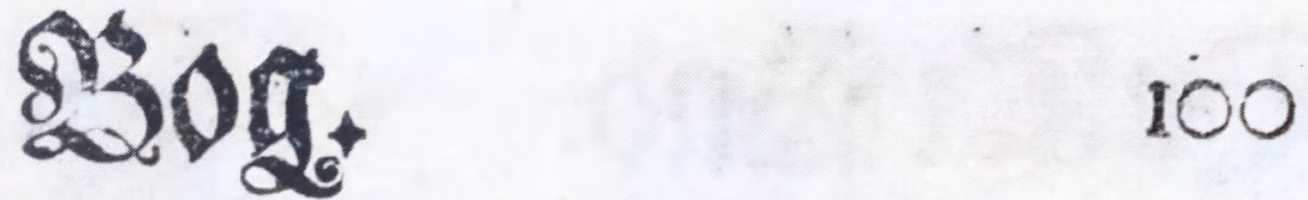

holoc fit 2 if. 43 Eomvaar 5 racrists dfenpaaflat Shardf iblant Suberittrute

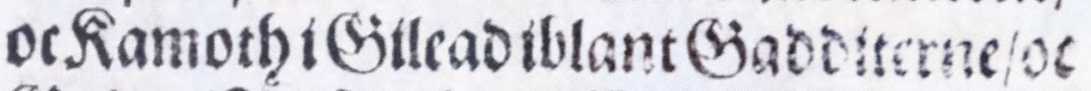
Golantỉafantblant\$2 anafitterne. 44 en Enne ar Lowen/ fom Szof frem: Co fatte for strats 3 orn: 4 fa oet

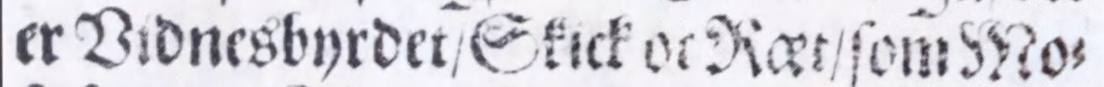
fe fagortil Sracts Born/ ocroc vane farne af Eunpten! 46 Paaltnfioe jo: Dan/ioen dalimoo prors bus/ierbons oen 2lmoriters Songis Sant fon foo i

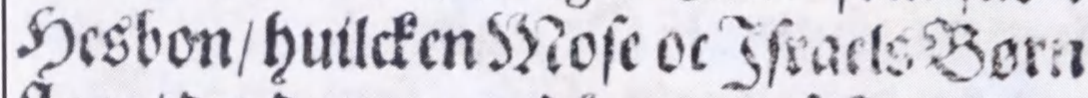


snittet er svært god. Ved gjennomgåelse av Chr. IV's bibel ser vi likevel en del unntak. Den første kommer så tidlig som på side $5 \mathrm{i}$ GT og er noe mindre i størrelsen $(25$ × 25 $\mathrm{mm})$, men snittet er som bibelens øvrige. Dette forekommer nok fordi noen av de gamle var ødelagt eller utslitt etter bruk til andre trykksaker, og det måtte derfor lages nye. I Fred. II's bibel har initialene, som er skåret i tre, samme kunstneriske utførelse, untatt to som kan ses på side 3 og 5 i GT, nemlig versal $\mathrm{O}$ og $\mathrm{D}$ hvor selve bokstaven er fyldt. Disse to forekommer ikke i Chr. IV's bibel.

Til sammen finnes 18 initialer skåret i et annet snitt i Chr. IV's bibel. Av disse finnes store kunstneriske variasjoner, og størrelsen varierer ( $28 \times 30$ og 34 x $30 \mathrm{~mm})$. Av initial G kan vi se på side 306 og 306b i GT hele tre forskjellige utførelser. Initialenes bokstaver er D, E, G, I, L og T, og de fleste har bilde med ramme rundt. Vi finner dem på sidene $5,111,214 \mathrm{~b}, 302,302 \mathrm{~b}, 303 \mathrm{~b}$, 306, 306b, 312, 319b, 320b, 321b, 322b, $330,331 \mathrm{~b}, 338 \mathrm{~b}$ og side $342 \mathrm{~b}$, alle brukt i Det gamle Testamentet og på side $89 \mathrm{~b}$ i NT, altså brukt i de to bibeldeler som ble trykt av Melchior Martzan.

Vi vet også at fra midten av 1500 -tallet ble det slutt med at hver boktrykker støpte egne typer. A støpe skrift var da blitt ett selvstendig håndverk.

Ved å lese noen sider i disse foliobibler ser vi setternes store problem med gemena/ minuskler v og u. Kanskje ikke så vanskelig å forstå når vi tenker på de håndskrevne manuskriptene de slet med.

SOM SLUT'TORD til disse betraktninger kan en forsiktig konklusjon være at eksakt gjenbruk til Chr. IV's bibel av Fred. II's typer til brødskriften er lite sannsynlig. Skriften ville jo forlengst blitt utslitt etter ca. 45 år mellom de to utgivelser. Typenes legering på et så tidlig tidspunkt hadde nok ikke samme kvalitet som senere i

skriftstøperienes historie. Fraktur er brukt i begge bibler, men med forskjellige skriftsnitt. En del initialer skåret i tre er byttet på grunn av slitasje eller skade (se avsnitt over). Slitte vignetter er også skiftet eller byttet til andre man mente var bedre (se f.eks. side 130a og b i NT).

For en lykkelig eier av disse vakre folianter, er det nok med et godt forstørrelsesglass for å oppdage interessante ulikheter og stor variasjon i skriftsnitt. Ett videre og mer inngående studium på dette område ville ha stor interesse for oss som samler på disse vakre og meget forseggjorte gamle bibler, som er typografiens kulturskatter i vår moderne datastyrte tid.

Hans H. Beckhaug 


\section{Ordforklaringer til}

\section{"Kirkebiblenes typografiske mangfold"}

Brødtekst: Den trykkskrift som det meste av en boks tekst er satt med. Tjente til sitt daglige brød, derav ordet.

Fisk: Ett uttrykk fra håndsatsens tid. Ordet brukes i forbindelse med dårlig utført avlegning eller uheld med satsen. Kan også brukes om en feil bokstav er kommet inn $\mathrm{i}$ ett ord.

Fraktur: Gotisk trykkskrift.

Initial: Markering av den første bokstav i kapitlet eller avsnitt i boken.

Kolumne: Fast antall tekstlinjer på siden for å skape like høye sider. Kolumnemål inkluderer også tittel og blindmateriell.

Majuskel: Skrift hvor alle bokstaver er like høye. (F.eks. store bokstaver ABCDEFGHIJ...)

Minuskel: Skrift hvor enkelte bokstaver har over- og underlengder (f.eks. har skrifttypen som brukes i ordforklaringen bokstaver som er lengre både oppover og nedover i forhold til x-høyden.

Versaler: Store bokstaver (dvs. majuskler).

Seriff: Uttrykk for tverrstreken som avslutter en bokstav oppe og nede.

Motsetningen er grotesk-skrift hvor bokstavene ikke avsluttes med tverrstrek.

Schwabacher: Gotisk trykkskrift som især ble brukt i Tysk typografi, men også i lande som stod Tyskland nær.

Skriftsnitt: Navngitt skrift til trykt eller skjermbasert typografi. Benyttes også om hver variant av en skrift. F.eks. Bodoni, Garamond og Baskerville for å nevne noen kjente.

Kustode: Nederst til høyre på hver side er det føyet til ett ord eller to for at setter og trykker skulle ha kontroll over siderekkefølgen. Kustoden i gamle bøker har den samme nytten for oss i dag, da vi lett kan kontrollere at alle sider i en bok er intakt.

x-høyde: Internasjonal betegnelse på høyden mellom de to midterste linjene i våre gemena bokstavers system med fire begrensningslinjer. Bokstav x er den eneste mellomlengdebokstav som i antikken har vannrette seriffer både oppe og nede.

Kapitéler: Versaler av brødskriftens xhøyde.

Matrise: Fordypet form som flytende bly kan presses inn i. Brukes til støping av skriftsats.

Patrise: Instrument til fremstilling av formen (matrisen).

Noter

Versene kom først i en dansk bibel i 1607 med Resens udgave, baseret på franskmanden Robert Estiennes græsk-latin bibel fra 1551.

I På Sporet af Gamle Bibler - en nordisk antologi. København, Akademisk Forlag, 1995.

Ibid.

Ibid.

-10 Illustrationer 